TEME, г. XLIV, бр. 3, јул - септембар 2020, стр. 845-861

Прегледни рад $\quad$ https://doi.org/10.22190/TEME190717026T

Примљено: 17. 7. 2019.

UDK $165.6 / .8$

Одобрено за штампу: 1. 10. 2020.

\title{
КУНОВЕ ИДЕЈЕ НАУЧНИХ РЕВОЛУЦИЈА И ОБЈЕКТИВНОСТ НАУКЕ
}

\author{
Катарина Томашевић ${ }^{1}$, Санела Андрић ${ }^{2 *}$, Срђан Милашиновић ${ }^{2}$ \\ ${ }^{1}$ Влада Републике Србије, Министарство унутрашњих послова, \\ Београд, Србија \\ ${ }^{2}$ Криминалистичко-полицијски универзитет, Београд, Србија \\ *sanela.andric@kpu.edu.rs
}

\begin{abstract}
Апстракт
Кунова књига Структура научних револуција покренула је лавину критика и представља најпревођеније и најкритикованије дело од шездесетих, па све до осамдесетих година двадесетог века, у коме се расправља о проблемима разумевања научног сазнања. Развој науке схватио је као постепени процес, током којег се смењују етапе нормалне науке и научних револуција. Смело уводећи нове појмове у историју филозофије науке, добио је много противника, али и много пратилаца. У раду смо покушали да прикажемо Куново схватање прогреса у науци и критике његових највећих опонената, са освртом на научне револуције у друштвеним наукама. Такође, покушали смо да одговоримо на питање да ли су научне револуције исцрпљене и шта се дешава са објективношћу науке.
\end{abstract}

Кључне речи: парадигма, нормална наука, научна заједница, криза науке, научна револуција, објективност науке.

\section{KUN'S IDEAS OF SCIENTIFIC REVOLUTIONS AND THE OBJECTIVITY OF SCIENCE}

\section{Abstract}

Kun's The Structure of the Scientific Revolutions triggered the avalanche of criticism and represents the most conducive and most critical work of the sixties, until the eighties of the twentieth century, in which the problems of understanding scientific knowledge are discussed. The development of science was understood as a gradual process during which the stages of normal science and scientific revolutions were being shifted. Boldly, by introducing new concepts in the history of philosophy of science, he has encountered many opponents, but also gained many followers. In this paper, we tried to present Kun's understanding of the progress in science and criticism of his greatest opponents, with a reference to the scientific revolutions in social sciences. We also tried to answer the question of whether the scientific revolutions have been depleted and what is happening with the objectivity of science.

Key words: paradigm, normal science, scientific community, crisis of science, scientific revolutions, objectivity of science. 
Структура научних револуиија представља најпревођеније, најкоментарисаније и најкритикованије дело од шездесетих, па све до осамдесетих година двадесетог века, у коме се расправља о проблемима разумевања научног сазнања. Аутор се у овом делу бави проблемима разумевања научног сазнања и пружа оригиналну слику механизама развоја науке. Кун научни развој схвата као постепени процес којим се скуп чињеница, теорија и метода додају растућем „складишту” конституишући научну технику и научно сазнање, док је историја науке дисциплина која хронолошки прати научни развој. Међутим, историчарима науке постаје све теже да испрате развој сазнања путем акумулације. Што више изучавају одређено научно поље, почињу да верују да је некадашни поглед на свет застарео, да су некадашња сазнања неспојива са овим која данас поседујемо. Наука иде унапред, научници спроводе истраживања, али нова сазнања не морају нужно да се приписују и надовезују на постојећа. Кад чланови одређене научне заједнице (у периоду нормалне науке) спроводе истраживања и тестирају теорије, може доћи до нових сазнања која нису у складу са претходним и са постојећом парадигмом, те тада наука може заћи у кризу. Тада долази до научне револуције и смене парадигми, а постојеће теорије бивају замењене новим које су неспојиве са претходним. Другим речима, Кун развој науке и научног сазнања види кроз револуције, а не кроз акумулацију. Период нормалне науке карактерише висока акумулативност и ширење обима и прецизности научног сазнања, док се прогрес у науци дешава кроз научне револуције.

\section{СТРУКТУРА НАУЧНЕ РЕВОЛУЦИЈЕ}

Структура научне револуције прати следећи ток: парадигма (научна заједница, нормална наука) - несавршености - криза науке научна револуција - нова парадигма. Међутим, овде Кун уводи могућност настанка нове парадигме пре настанка кризе, што води до сукоба две парадигме и недоследности у теорији. Долази до преображаја става нормалне науке и уводи се научна заједница која не дели исту парадигму. Шема нормална наука - криза - револуција јесте идеалнотипска и неодржива. Недоследност и криза нормалне науке настаје када се Кунова заједница „нормалне науке” суочи са неправилностима без средстава за њихово решавање, а већ постоји друга заједница која нуди решења датих неправилности. Овде долази до недоследности Кунове теорије, коју он не запажа. У кризи долази до пролиферације верзија парадигме и остаје отворено питање настанка нове парадигме с обзиром на то да пролиферација верзија парадигме не води њеном напуштању. Кунова теорија не задовољава услове рефлексије научне праксе и даје идеологизовано становиште парадиг- 
ме и кризе у науци саморазумевања. Суштину кризе науке чини то што ниједно становиште не може да објасни оно што друго може. Криза претходи револуцији, али је свест о њој могућа a posteriori. Нова парадигма је револуционарна једино онда кад превазилази стару и конкурентне, односно мора бити искуствено потврђена у старој парадигми (Брдар, 2014: 67-129). На крају, суд о разумевању спора између парадигми мора дати специјалиста, али као ваннаучни ауторитет.

Појмови које Кун уводи у филозофију науке, а помоћу којих објашњава развој научног сазнања су парадигма, нормална наука и научна револуција (Кун (Kuhn), 1974: 11-45; Николић \& Царић, 2016: 409). Парадигма представља скуп сазнања и теорија у оквиру одређене научне заједнице који служе као полазна тачка у научним истраживањима. Без научне парадигме сваки истраживач би морао своје научно поље да изграђује од темеља. Термин парадигма Кун употребљава у два смисла. С једне стране, он под тим термином подразумева сва уверења, вредности, технике и методе које деле чланови једне научне заједнице. С друге стране, тај термин означава конкретна решења загонетки нормалне науке. Кунова „нормална наука” представља редовно стање науке, истраживачку праксу која се заснива на одређеној парадигми која служи као критички основ научне праксе члановима одређене научне заједнице, активност у којој већина научника проводи скоро све своје време (Кун, 1974: 11-45; Николић \& Царић, 2016: 409). Нормална наука се састоји у решавању загонетки. Добра наука није ограничена правилима као што је то случај код Поперове оповргљивости и постулатима позитивизма. Суштина Кунове нормалне науке нису есенцијалне новине, али је усредсређена на езотеричне детаље, како их Кун назива, што на крају чини неизбежним да ће нормална наука наићи на потешкоће у владајућој парадигми (Nickles, 2003: 1). Ако се ове потешкоће нагомилају и постају критичне, парадигми прети криза. Нормална наука је дисциплинована у раду под парадигмом и њен задатак је да прошири и артикулише парадигму, а не да је тестира. Парадигма артикулише истраживачку традицију, научни живот, одређену дисциплину и њене практичаре (Nickles, 2003: 1). Кад одређена парадигма више није у стању да нуди објашњења, и критички оквир долази до кризе науке и појаве „научних револуција”, неуобичајених епизода у којима се догађа преокрет у професионалним опредељењима. „Научне револуције” су епизоде, етапе у развоју научног сазнања у којима научна заједница одбацује старе теорије и усваја нове које су неспојиве са старим теоријама. Научне револуције су ретке у науци, док су периоди „нормалне науке” дужи и они представљају редовно стање науке, а прогрес у научном сазнању могућ је само у периодима нормалне науке (Кун, 1974: 11-45; Николић \& Царић, 2016: 410). Најраније и најочигледније научне револуције повезују се са именима Коперника, Њутна и Ајнштајна. Свака од тих револуција во- 
дила је одбацивању постојеће теорије која је била прихваћена међу члановима научне заједнице и свака је довела до промене стандарда унутар професије и начину рашавања проблема (Окаса (Okasha), 2004: 91-96).

„Научна заједница” састоји се од оних научника који се активно баве једном специјалношћу, који су стекли слично образовање и који су усвојили исту техничку литературу (Кун, 2004: 240-246). Свака научна заједница има свој сопствени предмет истраживања, али постоје и школе у наукама, односно заједнице које истом предмету прилазе са различитих гледишта која су неспојива. Заједнице постоје на више нивоа. Најопштији ниво представља заједница свих природних/друштвених наука. На нижем нивоу се налазе професионалне научне групе: физичари, хемичари, астрономи, биолози, социолози, психолози, филозофи, историчари. На још нижем ступњу налазе се главне подгрупе: органски хемичари, аналитички хемичари, физичари чврстих тела, социолози рада, социјални психолози, историчари новог века.

Постојање заједничке парадигме за одређену научну заједницу не подразумева нужно постојање заједничких правила. Кад научник приступа истраживању унутар одређене парадигме, он мора превасходно да открије шта је то што су остали чланови заједнице издвојили као значајно и истражили, па тек онда приступити продубљеном проучавању поља интересовања, али не нужно на основу правила и поступака које су користили његови претходници. Заједничка основа је неопходна (истраживачки проблеми и технике у оквиру одређене научне традиције), али не и чврста заједничка правила.

Предуслов за нормалну науку представља заједничка парадигма. Период нормалне науке представља период истраживања (унутар одређене научне заједнице у оквиру одређене научне парадигме) коja су заснована на претходним научним достигнућима, током којег научници објављују резултате својих истраживања у научним уџбеницима и часописима, дефинишући проблеме и методе унутар одређене научне области за будуће генерације научника-практичара. Наредне генерације научника спроводе истраживања и тестирају постоjeће теорије проширујући фонд научних сазнања унутар одређене научне области. Нормална наука обухвата обичне свакодневне активности којим се научници баве и састоји се у проширивању знања о чињеницама које парадигма истиче као чињенице. Већина научника током читаве своје каријере ради на проширивању знања унутар одређене парадигме, односно проведе своју каријеру решавајући загонетке у периоду нормалне науке и не доживи да посведочи о научној револуцији. Кун активности научника у периоду нормалне науке назива „решавање загонетки”, којима се акумулирају и прецизирају сазнања. Резултати истраживања добијени у периоду нормалне науке значајни су јер доприносе обиму и прецизности сазнања у ок- 
виру одређене парадигме. Иако овако срочено звучи једноставно, на научницима-практичарима је велика одговорност и напоран рад на одржавању парадигме и проширивању постојећих сазнања.

Основна разлика у Куновој Структури јесте разлика између нормалне и револуционарне науке, као и несамерљивост између стаpe и нове парадигме (Nickles, 2003). Период нормалне науке карактерише константна акумулација и повећање прецизности сазнања. Током њега се не постижу новитети, већ се утврђују постојеће чињенице и теорије. Међутим, научници током својих истраживања у периоду нормалне науке стално долазе до нових сазнања. Овде је реч о случајним открићима, али они никако не значе кризу науке и смену парадигме. Приликом продубљеног истраживања одређених чињеница, научници случајним открићем долазе до нових чињеница, али оне не воде до смене парадигме. ${ }^{1}$

До смене парадигме у научној заједници долази онда кад се догоди темељна промена у начину на који се нормална наука наставља, односно кад се јави криза науке. Случајна открића могу (али не нужно) допринети промени парадигме, јер кад научна заједница усвоји откриће, њени чланови настоје да пруже објашњење за нове појаве, али нису једини извори промене парадигми. Кад се у науци наиђе на толике неправилности које трају дуго и кад парадигма више није у стању да објасни све појаве у нормалној науци и да понуди одговарајућа решења, тад долази до кризе науке. Коперникански обрт представља типичан и најчувенији пример промене парадигме. Птоломејски (геоцентрични) систем био је успешан у предвиђању промене положаја звезда, али није био у потпуности усклађен са посматрањима која су била извршена. Традиционална астрономска парадигма је подбацила и на њено место је дошла нова.

Кризе су предуслов настанку нових теорија, али научници се не одричу одмах старе парадигме која је „запала” у кризу. Они настављају да испитују одбацивање парадигме, јер да би претходну коja је дошла у кризу прогласили неважећом, мора да постоји друга ривалска парадигма која ће доћи на њено место. Одлука да се једна парадигма одбаци подразумева одлуку да се прихвати друга. Ако би се парадигма одбацила чим се уоче неправилности и наступи криза науке (а није се појавила ривалска несамерљива парадигма), негирао

\footnotetext{
${ }^{1}$ Кун као пример наводи откриће кисеоника. Пристли је у својим експериментима над црвеним оксидом живе добио гас који је идентификовао као водонични оксид флогистон. Лавоазије је каснијим истраживањима утврдио да се грејањем црвеног оксида живе добија чист ваздух (кисеоник). Међутим, откриће кисеоника није водило настајању нове парадигме у хемији. Откриће X-зрака представља случајно откриће, док је Рендген истраживао својства нове радијације, коју је већ открио. Видети: Кун, Т. (1974). Структура научних револуција. Београд: Нолит.
} 
би се цео корпус знања у одређеној области и научници би морали да крену испочетка са радом и стварањем теорија.

Кад се у постојећој парадигми уоче неправилности, мора се наћи нова парадигма која ће исправити недоследности и наследити претходну. ${ }^{2}$ Све кризе почињу неправилностима унутар парадигме, што онемогућава даље нормално истраживање, односно истраживање унутар нормалне науке и могу се завршити на један од три начина: 1) нормална наука се на крају може показати способном да реши проблем који је првобитно изазвао кризу, 2) проблем се може опирати и радикално новим прилазима, те научници могу закључити да у њиховој области неће доћи ни до каквог решења, па се оставља са стране за неке наредне генерације научника, и 3) криза се може завршити настајањем новог кандидата за парадигму (Кун, 2004). Међутим, прелазак са једне парадигме на другу не представља кумулативни процес, већ се ради о реконструкцији сазнања на основу нових ставова. Кад се пређе са једне парадигме на другу, професија мења методе и циљеве истраживања. Прелазак на нову парадигму представља научну револуцију. Међутим, кад се појави нова парадигмакандидат, пре него што јој приступе, научници морају бити сигурни да је та парадигма у стању да испуни два услова. Прво, мора решити неки истакнут и општепризнат проблем с којим се не може изаћи на крај ни на који начин старом парадигмом, и друго, мора сачувати релативно велики део способности за решавање проблема који су се нагомилали у претходној парадигми (Кун, 2004: 233).

Променом парадигме научник мења поглед на свет. Старе теорије и поступци постају ирелевантни и морају се заменити новим. Научник после смене парадигме мења поглед на свет, али и даље гледа у исти свет. Птоломеј и Коперник су посматрали исти свет, али су га другачије видели и интерпретирали. Пристли и Лавоазије су гледали исто једињење и видели исти гас, али су га другачије назвали. То је оно што је битно код научних револуција - другачија интерпретација света. Нове парадигме које се рађају из старих усвајају речник и апарат који је раније коришћен, али ти стари термини и појмови улазе у нове међуодносе, другачије се интерпретирају.

\footnotetext{
2 Куново схватање научних револуција, односно прогреса науке кроз научне револуције и смене парадигми, у опозицији је са Поперовим схватањем „бацања хипотеза у свет”, где критеријум научног статуса теорије зависи од могућности њеног оповргавања, односно њеног побијања или провере. Видети: Попер, К., Лакићевић, Д. Д. (2002). Претпоставке и побијаґа: Раст научног знања. Издавачка књижица Зорана Стојановића.
} 


\section{Критике Куновог схватања прогреса у науци}

Структура научних револуција изазвала је бурне реакције међу историчарима науке, нарочито међу припадницима супротстављених становишта. Она је пре свега постала ривал делу Претпоставке и побијаға (Попер \& Лакићевић, 2002), а спор између куноваца и попероваца још увек траје. Ова два дела отворила су најутицајнију дебату XX века. Међутим, без обзира на то да ли је неко за Куна, против њега или је неутралан, нико не може порећи значај његовог рада у области науке, културе и политике (Видети: Nickles, 2003). У филозофији науке је доминирао логички позитивизам и Карл Попер кад је Кун започео писање Структуре и дао сасвим другачију слику науке.

Куну се највише приговара неодређеност појама парадигме, који је он у Постскрипту Структуре из 1970. године преименовао у дисииплинарне матрище, које се састоје из четири врсте заједничких обавеза које карактеришу одређену дисциплину и научну заједницу: 1) симболичких генерализација попут Њутнових закона; 2) метафизичких модела онога што свет заиста јесте (нпр. гасови који се састоје од мноштва молекула облика билијарске кугле који су у случајном кретању); 3) вредности и стандарда; 4) примера (exemplars) (према: Nickles, 2003: 3). Односно, дисииплинарне матрице састоје се од: 1) симболичких генерализација; 2) метафизичких уверења; 3) научних вредности; 4) хеуристичких модела и 5) примера конкретних решења загонетки (Према: Bird, 2000: 68). Рани критичари су називали Куна ирационалистом, субјективистом и релативистом због негирања да нам наука даје објективну истину о стварности, док је Попер изјавио да Кунова нормална наука представља опасност за науку и цивилизацију (према: Worral, y Nickles, 2003). Новији критичари виде Куна као извор постмодерног релативизма и културно-теоријског третмана науке, као и покретачем Ратова науке (Сардар, 2001). Поједини критичари су га сматрали политичким конзервативцем и елитистом који је својим великим утицајем уништио сваки покушај да се у догледној будућности развије демократска научна политика (Fuller, 2003).

Главна Кунова теза односи се на напредак науке кроз научне револуције и смену парадигми. „Наука је еволутивна, али је и револуционарна" (Nickles, 2003). Научници проводе свој век унутар нормалне науке, тестирајући теорије, проширујући и прецизирајући сазнања. Кад се јаве неправилности и парадигма више није у стању да објасни свет, долази до кризе науке и настанка научне револуције кад се стара парадигма у потпуности замењује новом. С друге стране стоји Поперово становиште о претпоставкама и побијањима, одно- 
сно о проверљивости теорија, према коме је теорија ваљана једино ако је подложна провери, односно оповргавању. ${ }^{3}$ Ајнштајнова теорија релативности задовољава Поперове критеријуме оповргљивости, док астрологија није положила тест. На удару његове критике прве су се нашле Марксова теорија историје, Фројдова психоанализа и Адлерова индивидуална психологија, односно њихова објашњавалачка моћ. Ове теорије могле су да објасне све што се догађа унутар области које су покривале (Маркс преко класне борбе, Фројд путем потиснутог у несвесно и Адлер својим индивидуализмом) (Попер \& Лакићевић, 2002). Наиме, Попер је хтео да повуче демаркациону линију између науке и псеудонауке путем критеријума проверљивости, односно оповргљивости, преко могућности оповргавања или могућности побијања. Он је сматрао да разграничавање представља решење већине проблема у филозофији науке, пре свега проблем индукције, ${ }^{4}$ док се значењем није бавио и сматрао га је тривијалним. За њега је астрологија псеудонаука јер није проверљива, односно оповргљива. Према Куну, прави разлог зашто астрологија није наука је тај што она нема традицију решавања загонетки и није напредовала до стања нормалне науке (Worral, 2003: 70). Кун је сматрао Поперову теорију оповргљивости погрешном због увођења могућности да се теорија одбрани од потенцијалног одбијања увођењем споредног податка или испитивањем података. На овај начин се, тврди Кун, свака теорија може модификовати ad hoc прилагођавањима док не престану да буду исте теорије. Ми ћемо додати да се на овај начин свака теорија може подвргнути критеријуму оповргавања и доказати тачном, што је у крајњем случају не разликује од Марксове, Фројдове и Адлерове теорије коју је Попер толико критиковао.

Дебата Кун-Попер започета је на интернационалном научном колоквијуму (конференцији) историчара филозофије науке који је организовао Лакатош, бранилац Поперовог становишта (Fuller, 2003: 10). Међутим, за разлику од Кунове Структуре, ниједан рад није сажео Поперову позицију. Он је сматран филозофом коме је наука била погодно средство за артикулисање сопственог погледа на свет.

Логички позитивисти Бечког круга, коме је Попер некад припадао, били су усмерени ка стварању језика који ће објаснити научне

\footnotetext{
${ }^{3}$ Марксова теорија, Фројдова психоанализа и Адлерова индивидуална психологија нису оповргљиве теорије и помоћу њих се може све објаснити, те их Попер сматра лошим теоријама. Ниједна ваљана теорија не може објаснити све, већ само проблеме унутар поља у коме се користи.

${ }^{4}$ Оно што је заједничко Куну и Поперу јесте критика индукције, као метода којим се све може објаснити, односно, објашњење случајева о којима нисмо имали искуство на основу случајева о којима смо имали искуство. Аутори су сагласни да се на овај начин Фројдовом психоанализом могу објаснити све појаве у свету.
} 
доказе и закључке на начин који ће бити разумљив грађанима и он је био привржен њима у овим напорима. Међутим, неопозитивисти били су суочени са растућим јазом између научног и стручног знања. Поперово неслагање са позитивистима долази до изражаја у њиховим ставовима о улози логичке дедукције у науци и управо у овом контексту је формулисао свој концепт проверљивости, за који је тврдио да ће повући демаркациону линију између науке и псеудонауке. ${ }^{5}$ Позитивисти су сматрали да дедукција представља повезаност мисли, нарочито указујући на то како опште знање може да објасни оно мање опште. За њих је дедукција алат за присиљавање научника да тестирају последице својих тврдњи о општем знању у одређеним случајевима који могу бити у супротности са налазима емпиријског истраживања (Окаса, 2004: 20-44). Међутим, управо ово представља принцип проверљивости (falsification) и Попер је сматрао да је он много више него један од многих начина употребе логике (третирао га је као језгро научне етике). Ово нас доводи до закључка да било које веровање може бити научно или не, у зависности од тога да ли је неко покушао да га тестира, односно да тестира границе његове вредности. Са Поперове тачке гледишта, оно што су позитивисти сматрали интересантним у вези са дедукцијом била је једва ad hoc рационализација истраживачког процеса. С друге стране, Кун је прихватио Поперову критику позитивизма, али није пронашао историјску основу проверљивости као радне етике у науци. Попер је, опет, сматрао да се историцизам крије иза многих наизглед неповезаних позиција: знања путем индукције, легитимације путем традиције, еволуције природном селекцијом, пролетерске револуције историјским материјализмом (Попер \& Лакићевић, 2002: 78-82), док је Кун подржао историцизам као део научне обуке (Кун, 1974).

Попер је револуције попут Галилејове и Ајнштајнове пре сматрао изузетком у историји науке него правилом, тумачећи Кунову нормалну науку као морални неуспех, а не успелу стратегију адаптације. Међутим, последњих двадесет година у историји, филозофији и социологији науке доминира нова генерација научника која узима Кунову Структуру као непроблематичну основу својих истраживања, што Попер сматра проблематичним. Он сматра да је куновска нормална наука политички примитивна друштвена формација и да научници треба увек да покушавају да побијају/оповргавају/проверавају своје теорије. С друге стране, Поперова стратегија за изазивање доминантних теорија има циљ да науку учини игром (Попер \& Лакићевић, 2002). Сви научници који раде унутар једне парадигме су

\footnotetext{
${ }^{5}$ Попер је негирао индукцију као ваљан начин закључивања који може довести до грешака у изношењу закључка.
} 
равноправни, али су неки равноправнији од других. Једини начин на коме куновски научници диктирају услове свог истраживања јесте тај што су сви сагласни и што се придржавају одлука својих истомишљеника. На овај начин се обезбеђује јединствен фронт легитимитета за ширу заједницу. Тако је Попер имао препознатљиву примену универзалног карактера научне рационалности. Озбиљно је сматрао да наука тежи универзалном знању и да су научници непогрешиви. Као резултат свега тога, интелектуална дискриминација наставља да се употребљава као ненасилно средство друштвене контроле. Иако ни Кун ни Попер нису хтели да порекну да одређена парадигма може да доминира разумевањем одређеног дела стварности у одређено време, они се разликују у погледу тога да ли то треба третирати као извор стабилности, што је случај код Куна, или као проблем који треба савладати, што је случај код Попера. Куново „победник односи све" виђење парадигме односи се на то како јавност разумева научно сазнање, помоћу које се иновације расподељују. Кунов плурализам је невољан исход присиљен његовим брендом универзализма, док је Попер пожељно прихватио плурализам као средство за реализацију свог бренда универзализма (Fuller: 2003). За Куна, науком увек доминира једна парадигма, коју њени чланови следе религиозно, док год она не досегне границе својих способности у решавању загонетки. За Попера је плурализам суштински свакодневно спровођење научних истраживања, јер се научници подстичу на пролиферацију алтернативних хипотеза које се касније суочавају са крутим унакрсним испитивањем стандарда који указују на универзално слагање (бацање хипотеза у свет). Да би били сигурни, поперовци су наглашавали да научници могу рационално наставити да се баве хипотезама и након што су оне оповргнуте, али само да би се препознало оно што би требало да промени умове других истраживача. На најширем филозофском плану, Кун и Попер представљају два радикално различита начина одређивања циљева истраживања (Кун, 1974; Попер \& Лакићевић, 2002).

Попер је унапредио верзију своје стратегије напада на „мит о оквирима (енгл. framework)", куновску идеју да је присуство несамерљивих теорија тешко пружало било какво експлицитно нормативно поређење тако да је требало сачекати историју да усвоји једну или другу теорију. Насупрот томе је тврдио да ако су несамерљиве теорије заиста научне, оне желе универзалност, што значи да ће бити случајева које још нису објасниле или предвиделе. ${ }^{6}$ Попер је био демократа заинтересован за науку као облик динамичког истраживања,

\footnotetext{
${ }^{6}$ Овде Попер сугерише да не треба одбацивати старе теорије/парадигме, јер ће оне у будућности моћи да објасне неке друге феномене. Научници не одбацују оповргнуте хипотезе, већ настављају да се баве њима.
} 
док је Кун био елитиста усредсређен на науку као стабилишућу друштвену праксу. Упркос томе, њима су ове особине приписиване у обрнутом смеру. Ако је Попер био „научан” или „позитивистичан”, управо то је био смисао, он је желео да друштво буде реорганизовано тако да може да буде истински експериментално, као научна лабораторија за своје хипотезе. Циљ који је био заједнички и Куну и Поперу била је идеја „планиране науке” (Fuller: 2003).

Разлике између Куна и Попера досежу дебату о улози универзитета у друштву. За некога ко је техничку обуку сматрао најважнијим друштвеним процесом у одржавању и промовисању нормалне науке, Кун је изузетно мало рекао о томе где би ова обука требало да се одржава. Слично њему, и Попер је придавао мало значаја универзитету у обликовању његових идеја, упркос својој докторској обуци у педагогији, али би се обојица могла сагласити да наука захтева суштински друштвену епистемологију. Уџбеници, који све више комбинују квалитете приручника за обуку и резиме утврђених налаза, заједно опремају почетника за будућу праксу. Оно у чему су ова два научника сагласна јесте да се наука не развија „нагомилавањем”, наглашавајући да су промене на нивоу фундаменталне теорије понекад биле радикалне или револуционарне. Неслагања произлазе из њиховог схватања обима и механике тих промена (Worral, 2003: 66).

Занимљиво је још рећи да Кун никад није дао одговор на критике које су му упућене. Недостатке и недоследности које је приметио у Структури и на које су му блиски пријатељи скренули пажњу образложио је у постскрипту издања из 1969. године. Дебату КунПопер започели су и воде је и даље куновци и поперовци.

\section{Научне револучије у друштвеним наукама}

Кунова Структура научних револуција говори о кризи науке и смени парадигми у историји природних наука. Исцрпно су наведене најкарактеристичније и најпознатије научне револуције које су промениле поглед на свет одређених научних заједница и утицале на промену тока истраживања и напредак научног сазнања. Међутим, с правом можемо поставити питање шта се дешава са друштвеним наукама. Како настаје смена парадигме у друштвеној науци и како она утиче на научну заједницу?

Рекли смо да до куновске смене парадигме долази кад научници током истраживања у периоду нормалне науке наиђу на неправилности унутар парадигме и кад она више није у стању да пружи ваљана објашњења; тада наука запада у кризу и јавља се нова супарничка парадигма која је неспојива са постојећом. Сменом парадигме долази до промене погледа на свет и научници настављају своје активности унутар нове парадигме и почиње период нормалне науке. Међутим, ово је случај са природним наукама. У друштвеним наука- 
ма је ситуација другачија, ту супротстављене парадигме коегзистирају и развијају сазнања и теорије који се надмећу у објашњењу света. Одређена појава може се објаснити са позиције позитивизма, историзма, прагматизма и сва та схватања коегзистирају нудећи своје виђење света. Научници одабирају одређену парадигму и унутар ње акумулирају сазнања, али не долази до одбацивања и смене парадигме. Кључну разлику прогреса у природним и друштвеним наукама даје чињеница да научна револуција у природним наукама доводи до потпуне замене једне парадигме другом, док у друштвеним наукама то није случај, већ различити референтни оквири истраживања друштвених појава нису постали и не могу да постану релативно општеприхваћене „дисциплинарне матрице” пошто се међусобно трајно супротстављају и коегзистирају (према: Вратуша-Жуњић, 1995: 9).

Класични пример две супротстављене парадигме у друштвеној науци представљају Контов позитивизам и Марксова дијалектика (у периоду конституисања социологије као нове науке о друштву средином XIX века). Конт је на почетку своје научне каријере сматрао да је циљ науке и научног деловања да служи побољшању живота људи који су израбљивани од стране претпостављених. Касније је променио поглед на циљеве и улогу социологије у друштву, сматрајући да је њен задатак „рационална научна спознаја позитивних природних закона друштвеног поретка и прогреса људског духа” и да „треба да послужи као теоријски инструмент ефикасног оријентисања и предвиђања последица политичке акције с циљем задовољења потреба управљања и мирне реорганизације друштва" (Вратуша-Жуњић, 1995: 4). На овај начин се, према Конту, прелази из старог у нови систем. Институционализована је позитивистички оријентисана социологија, која је добила државну подршку као академска дисциплина и потиснула веронауку из наставе у јавним школама. Социологија је била неопходна владајућој класи (класи колективних власника), која има монопол над поделом рада, као теоријско средство за успостављање идеолошко-политичке хегемоније у друштву. С друге стране, Маркс је у сличном историјском периоду одговор на питање о задацима научне спознаје друштва дао са критичког становишта, односно са становишта дијалектичког материјализма и разумевања односа између производних снага. Према Марксу, основни циљ науке није пуко тумачење света, већ измена света (према: Вратуша-Жуњић, 1995: 417-431). Допринос науке о друштву је видео у освешћивању потребе пролетеријата/потлачене класе за револуцијом и преображајем постојећег облика организације друштвене репродукције, укидањем старих односа производње и успостављањем нових.

Контова позитивистичка парадигма тумачи односе у друштву по угледу на природне науке, док Марксова критичка парадигма тумачи законе у друштву кроз односе репродукције. Из ова два схватања друштвене стварности изводе се разлике у схватању друштвене 
теорије и науке. Прво становиште је усмерено на контролисање незадовољства и поправљање судбине подређених слојева/класа у хијерархијски уређеном друштвеном поретку, док друго истиче науку као поглед на свет и теоријско оруђе за освешћење подређених клаca, укидањем класне поделе рада. Контова и Марксова парадигма опстају као класици социолошке науке (заједно са Диркемовом и Веберовом), а њихови следбеници развијају научне теорије и проширују сазнања без смене парадигми.

\section{ОБЈЕКТИВНОСТ НАУКЕ}

Објављивање Кунове књиге о научним револуцијама покренуло је лавину критика и рат између научника. Многи су критиковали његово дело и оптужили га за релативизам, док су други радосно дочекали његове идеје и схватања о напретку науке (Брдар, 2014). Кад је изашла Кунова Структура, водећа школа у филозофији науке била је она која је формирана око Бечког круга и Карла Попера. Круг се заснивао на доктрини да су метафизика и теологија безначајне јер се састоје из тврдњи које се не могу проверити. Попер је био заступник логичког позитивизма и заступао је став да у науци нема коначне истине и да се научни напредак постиже „претпоставкама и побијањима" (Сардар, 2001). С друге стране, Кун је револуције у науци поредио са револуцијама у политици, теологији и уметности, тврдећи да се научни напредак постиже сменама парадигми. Управо из ових супротстављених гледишта произашао је ривалитет између аутора и оспоравање Куновог дела од стране Попера и попероваца. Са критика значења „парадигме”, преко оптужби за релативизам, Кунову „нормалну науку” заменила је корпорацијска, индустријализована наука.

У природним наукама истраживачи врше експерименте помоћу прецизних инструмената након, чега се врши очитавање и интерпретација резултата. Циљ експеримената је проналазак нових изума и патената који ће направити научну револуцију. У друштвеним наукама је другачије. Експерименти у строгом смислу речи се не могу вршити из етичких разлога, па се врше разна опсервирања, испитивања, анализе садржаја и дескрипције. Истраживања се све чешће прилагођавају наручиоцу уместо научном циљу. Настанак теорија о друштву условљен је доминантним друштвеним односима између основних друштвених групација и актера, имају улогу тзв. Партијског оружја и усмеравају друштвене процесе у жељеном смеру (Вратуша-Жуњић, 1995: 417-431).

Попут истраживача у природним наукама, и друштвени научници током социјализације и образовања усвајају одређени корпус схватања, ставова и сазнања. Као такав, друштвени научник не може 
да буде веберовски неутралан јер заузима став у односу на предмет свог истраживања. Посматрајући клатно и планете кроз телескоп, истраживач у природним наукама не заузима став према телескопу или клатну, док истраживач у друштвеним наукама заузима став према насилнику у породици, безбедносним ризицима и криминалитету. Да ли онда можемо причати о објективности друштвених наука? У друштвеним наукама је веома тешко доћи до објективно потврђених објашњења друштвених појава због њиховог вредносног и субјективног аспекта (према: Нејгел (Nagel), 1974: 421-431). Вредности и појаве у друштву могу се само чулно опажати; јединице анализе у (социолошким) истраживањима не могу се истражити физичким мерним инструментима (телескоп, микроскоп, спектрометар), већ мерним инструментима које израђује са̂м научник за потребе и циљеве истраживања (варијабле, упитници, скале, типологије, класификације). Друштвене науке теже да разумеју друштвене појаве путем мисаоних категорија дајући им субјективна значења. Научник који проучава друштво је и са̂м учесник у истраживању, он уноси сопствено искуство и на основу њега је у могућности да разуме унутрашње значење друштвених појава и акција. Друштвени научници се разликују на основу вредности које прихватају, па је вредносна неутралност дискутабилна, а прецизност утврђивања и објашњења чињеница попут природних наука тешко докучива (Нејгел, 1974: 421-431). Друштвени научници се ослањају на вредносне судове при избору проблема, одређивању садржаја закључака, при идентификовању чињеница и при процењивању сведочанстава (Нејгел, 1974: 421-431). Међутим, људско понашање није толико непредвидиво и има разлике кад социолог и лаик описују и дају објашњење таквог понашања. Дескрипција и објашњење у друштвеним наукама нису строго субјективне категорије, оне су засноване на одређеном корпусу знања, закона и теорија. Израдом прецизног плана истраживања, затим израдом протокола и базе података значајно се повећава прецизност истраживања у друштвеним наукама и на тај начин добијених података. Израдом плана истраживања даје се упутство истраживачима како доћи до људи на терену, на који начин прикупљати податке и направити базу података која касније омогућава секвенцијалну анализу и проверу резултата. Стандардизација метода друштвених наука такође повећава прецизност истраживања и олакшава сређивање и опис података, доприносећи повећању објективности (Милашиновић \& Андрић, 2016: 431-442; Андрић, 2017: 78-85).

На крају, да би постигао вредносну неутралност, истраживач мора бити свестан своје улоге у друштву и предмета свог истраживања, односно свог хабитуса. „Наука зарад науке”, а не зарад појединачних циљева, једино тако се може постићи објективност у науци. Научник заузима одређени став према проблему који истражује и 
има своје почетне хипотезе, али се добијени резултати анализирају и интерпретирају вредносно неутрално (Вебер (Weber), 1976: 4-8; Вебер, 1989: 21-84).

\section{ЗАКљУЧАК}

Прогрес у наукама постиже се путем научних револуција, које представљају ретке цикличне епизоде у науци. Кад парадигма западне у кризу и не може на адекватан начин да решава загонетке, јавља се нова парадигма, која је неспојива са старом. Научне револуције прате ток: парадигма - нормална наука - неправилности - криза - научна револуција - смена парадигме - нормална наука. Већина истраживача проведе животни век унутар нормалне науке, тестирајући теорије, акумулирајући и прецизирајући сазнања.

Структура научних револуција изазвала је бурне реакције међу историчарима науке, нарочито међу припадницима супротстављених становишта. Она је постала ривал Поперовом делу Претпоставке и побијања, а спор између куноваца и попероваца још увек траје. Главни ривал Куновом схватању прогреса науке кроз научне револуције представља Поперово схватање о бацању хипотеза у свет и потврђивању научних теорија могућношћу њиховог оповргавања. Основе разлике између ова два аутора налазе се у схватању научног прогреса и односу према историцизму. Према Куну, прогрес у науци не постиже се акумулацијом сазнања, већ путем научних револуција, док Попер сматра да је главни критеријум научног статуса теорије могућност њеног побијања. Затим, Попер је сматрао да се историцизам крије иза многих наизглед неповезаних позиција: знања путем индукције, легитимације путем традиције, еволуције природном селекцијом, пролетерске револуције историјским материјализмом, док је Кун подржао историцизам као део научне обуке.

Кунова Структура детаљно описује примере научних револуција у природним наукама, односно у физици. Међутим, у друштвеним наукама је другачије, супротстављене парадигме коегзистирају и развијају сазнања и теорије који се надмећу у објашњењу света. Научна револуција у природним наукама има тенденцију да доведе до потпуне замене једне парадигме другом, док у друштвеним наукама различити референтни оквири истраживања друштвених појава, односно различите парадигме, нису и не могу да постану релативно општеприхваћене „дисциплинарне матрице” пошто се међусобно трајно супротстављају. Теорије социолошких класика Конта, Маркса, Диркема и Вебера опстају као супротстављене парадигме и намећу своје виђење света, друштва и друштвених односа.

Да ли имамо објективну науку која може све да објасни? Или нам остаје да науку прихватимо као парадигму и верујемо њеним ре- 
зултатима? Научници који се баве проучавањем друштва имају однос према предмету истраживања и заузимају став према њему, али се само истраживање спроводи објективно, употребом научних метода. Уколико се бавимо „науком зарад науке”, уколико имамо свест о свом „хабитусу” и месту и функцији у друштву, уколико имамо свест коме и чему треба да служи наука о друштву, само на тај начин ћемо обезбедити неутралност и објективност у науци.

\section{ЛИТЕРАТУРА}

Bird, A. (2000). Thomas Kuhn. UK: Acumen Publishing Limited.

Fuller, S. (2003). Kuhn vs Popper. UK: Icon Books LTD.

Nickles, T. (2003). Thomas Kuhn. New York: Cambridge University Press.

Андрић, С. (2017) Пројектовање научног истраживања [Scientific research design]. Српска наука данас. 2(1) 78-85.

Брдар, М. (2014). Наука и истина [Science and truth]. Крагујевац: Центар слободачких делатности.

Вебер, М. (1976). Привреда и друштво [Economy and society]. Београд: Просвета.

Вебер, М. (1989). Методологија друштвених наука [Methodology of social sciences]. Глобус, Загреб.

Вратуша-Жуњић, В. А. (1995). О смени доминантне парадигме у друштвеним наукама [About of the change of the dominant paradigm in the social sciences]. Сочиолошки преглед, 3, 417-431.

Кун, Т. (1974). Структура научних револуиија [The structure of scientific revolutions]. Београд: Нолит.

Милашиновић, С., Андрић, С. (2016) Студија случаја у истраживању политичких појава [Case study in the study of political phenomena]. Култура полиса, XIII(30), 431-442.

Нејгел, Е. (1974). Структура науке [The structure of science]. Београд: Нолит.

Николић, 3., Царић, М. (2016) Преламање парадигми - Кунова, Поперова, Хусерлова и Гадамерова перспектива [Paradigm reversal - Kun, Popper, Husserl and Gadamer perspectives]. Култура полиса, XIII(29), 407-420.

Окаса, С. (2004). Филозофија науке [Philosophy of science]. Сарајево: ТКД Шахинпашић.

Попер, К., Лакићевић, Д. Д. (2002). Претпоставке и побијања: Раст научног знања [Assumptions and refutations: The growth of scientific knowledge]. Издавачка књижица Зорана Стојановића.

Сардар, 3. (2001). Томас Кун и ратови знаности [Thomas Kun and the Wars of Science]. Загреб: Наклада Јесенски и Турк. 


\title{
KUN'S IDEAS OF SCIENTIFIC REVOLUTIONS AND THE OBJECTIVITY OF SCIENCE
}

\author{
Katarina Tomašević1, Sanela Adrić2 ${ }^{2}$, Srđan Milašinović ${ }^{2}$ \\ ${ }^{1}$ The Government of the Republic of Serbia, Ministry of Interior, Belgrade, Serbia \\ ${ }^{2}$ University of Criminal Investigation and Police Studies, Belgrade, Serbia
}

\section{Summary}

Kun gives an account of radical changes in the image of science and boldly introduces new concepts in the philosophy of science. The key terms that he uses are "paradigm" and "normal science" that are necessary for understanding the development of scientific knowledge, and although his book has come under sharp criticism, these concepts have become widely accepted later on. Kun's critics through the prism of ideology discuss his theories. However, Kun was confirmed precisely through controversy.

Under the term "paradigm" Kun implies the basic theory of scientific achievement that provides a certain scientific community with a model of learning in the form of generally accepted ideas; universally accepted scientific achievements. These are all beliefs, values, and procedures that are common to members of one scientific community, a standard set of methods from a particular field, the basis from which the study begins. The paradigm is common to members of a scientific community and, in the period of normal science, members of the scientific community solve puzzles and accumulate knowledge. The crisis of science occurs when members of the scientific community find inconsistencies and irregularities within a paradigm.

Scientific revolutions are non-accumulative episodes in science that replace the old paradigm with a new one, which is incompatible with the old. Such episodes are rare in science (as opposed to a period of normal science in which researchers spend almost their entire career) and represent a progressive development of science. Science evolves by changing the paradigm, and in order for the new paradigm to be adopted, it must obtain the approval of the scientific community.

Progress in science occurs through scientific revolutions, not accumulation of knowledge. Kun rejected the fact that the history of science follows linearity, continuity, cumulativity and unity, but that, like other cultural institutions, discontinuity, unwillingness and disunity are observed, and that its products are constructed and invented just as they were discovered.

All of the above applies to natural sciences, however, with social sciences, the situation is different. The invention of the new paradigm does not reject the old, but rather exists and develops as separate "schools of thought". Several different schools of thought can observe a particular problem or phenomenon from different points of view, and they will not mutually push each other. Positivism, normativism, history, behaviorism and biology will study and observe the same problem or phenomenon in different ways, give different definitions, classifications and theories, with each direction having its followers and successors. In the end, this is the case with Kun's and Popper's standpoint. 